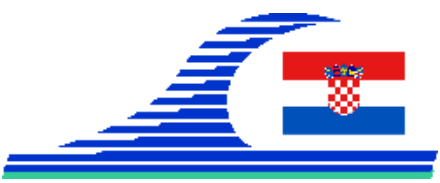

Conférence Méditerranéenne Côtière et Maritime

EDITION 4, SPLIT, CROATIA (2017)

Coastal and Maritime Mediterranean Conference

Disponible en ligne - http://www.paralia.fr - Available online

\title{
Coastal erosion and instability phenomena at Stara Baška, Krk Island, Croatia
}

\author{
Igor RUŽIĆ ${ }^{1}$, Čedomir BENAC ${ }^{1}$, Sanja DUGONJIĆ JOVANČAVIĆ ${ }^{1}$, \\ Leo MATEŠIĆ ${ }^{1}$
}

1. University of Rijeka, Faculty of Civil Engineering, R. Matejčić 3, 51000 Rijeka, Croatia.

iruzic@.uniri.hr

\begin{abstract}
:
The paper describes the influence of the marine erosion and slope instabilities on cliff retreat in the coast near Stara Baška settlement on Krk Island (northeastern channel part of the Adriatic Sea). The bedrock is occasionally covered by breccia from Quaternary period. The coast around Stara Baška is exposed to wave attack and thereby to marine erosion. By comparison of orthophoto maps from 1966 and 2004, the significant coastal retreat was determined. This phenomenon has been a fundamental trigger off different instability phenomena. The type of instabilities is a consequence of the local geological fabric and rock mass resistivity marine erosion. In the investigated area, rock falls and slumps prevail in cliffs formed in breccia. Extremely high tides with the combination of strong waves from southern direction have a significant influence on the coastal erosion. This is an indicator of the possible higher hazard degree caused by the sea-level rise.
\end{abstract}

\section{Keywords:}

Rocky coast, Cliff retreat, Slope instability, Wave attack, Marine erosion, Sea level rise, High tide, Adriatic Sea.

\section{Introduction}

Coastal cliff erosion is primarily influenced by the lithology, rock mass structure, and its geotechnical parameters. The recession of hard rock cliffs is usually the result of wave undercutting and subsequent removal of debris deposited at the cliff toe by coastal processes (TRENHAILE, 2002). The northeastern Adriatic coast is predominantly a steep, rocky coast formed of karstified carbonate sedimentary rocks. Geomorphology of this coastal area is complex and diverse (PIKELJ \& JURAČIĆ, 2013). Intensive morphogenetic processes caused by tectonic movements and by rapid sea-level changes have caused the recent shape of the Krk Island. In addition, slow sea-level rise during the last 6.000 years created conditions for more intensive marine erosion (BENAC \& JURAČIĆ, 1998). On carbonate, rocky coast bioerosion prevails and tidal notches are common. In coastal parts, where the rock mass is tectonically crushed or karstified, 
Mediterranean rocky coasts:

Features, processes, evolution and problems

wave-notches and cliffs were formed. Marine erosion and rapid cliff recession rates occur in the less-resistant siliciclastic rocky coast and Pliocene-Quaternary deposits (JURAČIĆ et al., 2009). Marine erosion in the Kvarner area is only locally expressed. Coastal zone near Stara Baška in the southeastern part of the Krk Island is exposed to significant coastal erosion (figure 1, 3). This paper presents the relationship between marine erosion, coastal changes and cliff retreat.

Coastal zone around Stara Baška is formed in Upper Cretaceous and Palaeogene carbonate and siliciclastic rocks, it is a typical bare karst. Limestones and carbonate breccias are tectonically strongly deformed and karstified. Palaeogene siliciclastic rocks such as marls and flysch are in the narrow coastal zone.

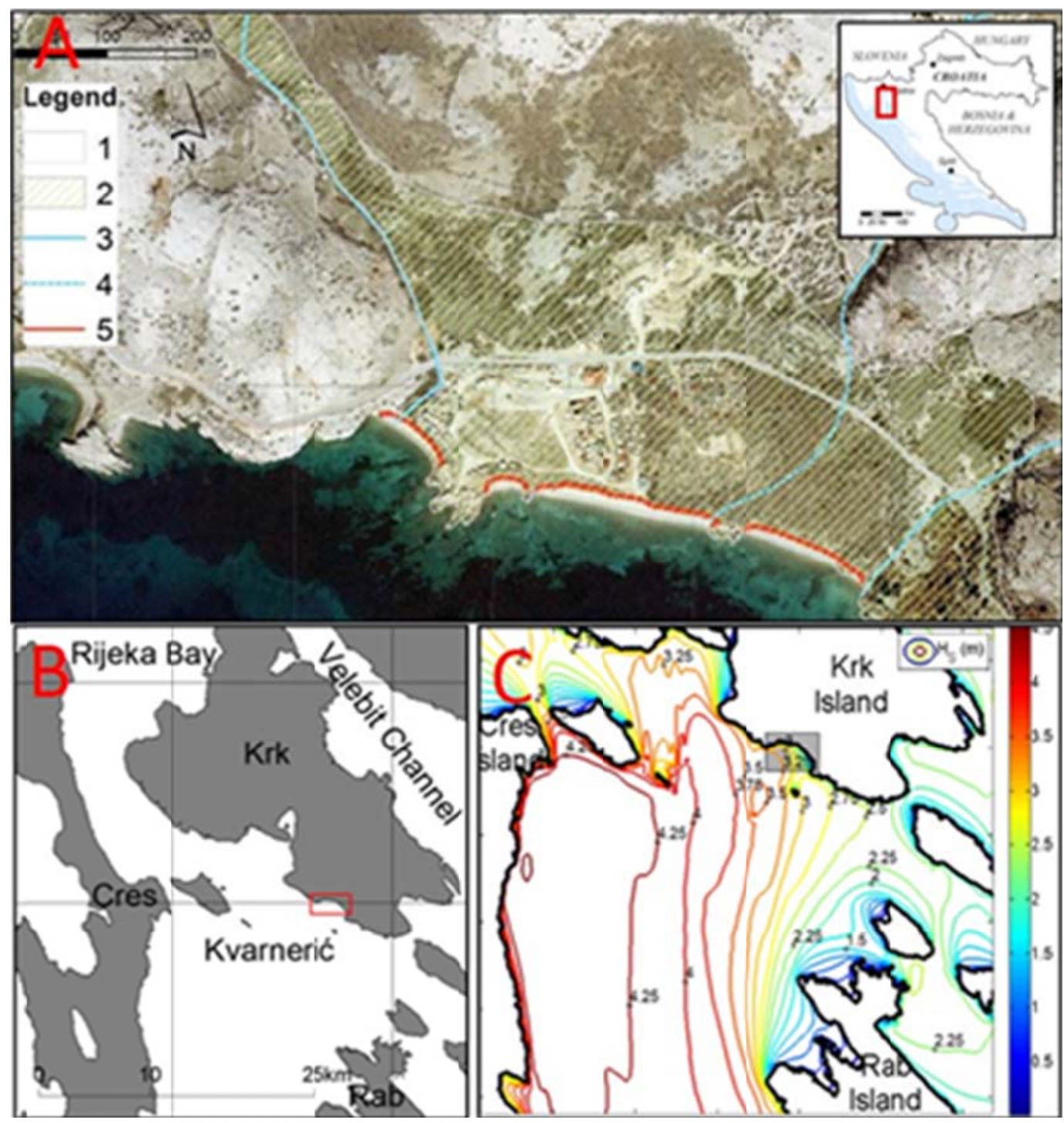

Figure 1. A: Coastal zone around Stara Baška geological map: 1-carbonate rocks, 2siliciclastic rock mass, 3-periodical surface water flow, 4-partially canalized water 
Mediterranean rocky coasts:

Features, processes, evolution and problems

flow, 5-cliffs; B: Study area; C: Significant wave height numerical simulation: $H^{S}(m)$, SE, $26.5 \mathrm{~m} / \mathrm{s}$, SWAN model.

\section{Marine erosion}

The slump of cliff slope can occur in rock mass of higher strength parameters, where the notches are cut few meters inward into the toe of cliff slope (figure 2). Siliciclastic or flysch bedrock is characterized by great lithological heterogeneity due to the vertical and lateral alternation of different lithological sequences. Marls and silltstone prevail in tectonically very deformed flysch rock mass which is more prone to mechanical and chemical weathering as well as different instability phenomena (figure 2). Talus breccias have pronounced horizontal stratification. Horizontal layers consist of limestone fragments, from few millimeters to blocks greater than $500 \mathrm{~mm}$ in size, where fragments from 10 to $40 \mathrm{~mm}$ prevail. Marine erosion is more pronounced on the coast formed in siliciclastic rocks, cohesive Quaternary and recent sediments. Due to talus production, narrow gravel pocket beaches are formed at the cliff foot. Cliffs formed in talus breccias have an average height up to 6 meters and have locally significantly retreated in period 1966 - 2004, (RUŽIĆ et al. 2014; 2015). The changes in the cliff and coastline position were defined by a comparison of geo-referenced aerial images from 1966 and 2004 (figure 3). Significant impact on the cliff retreat has wave-induced erosion. This resulted in an increase of the beach area (figure 3).

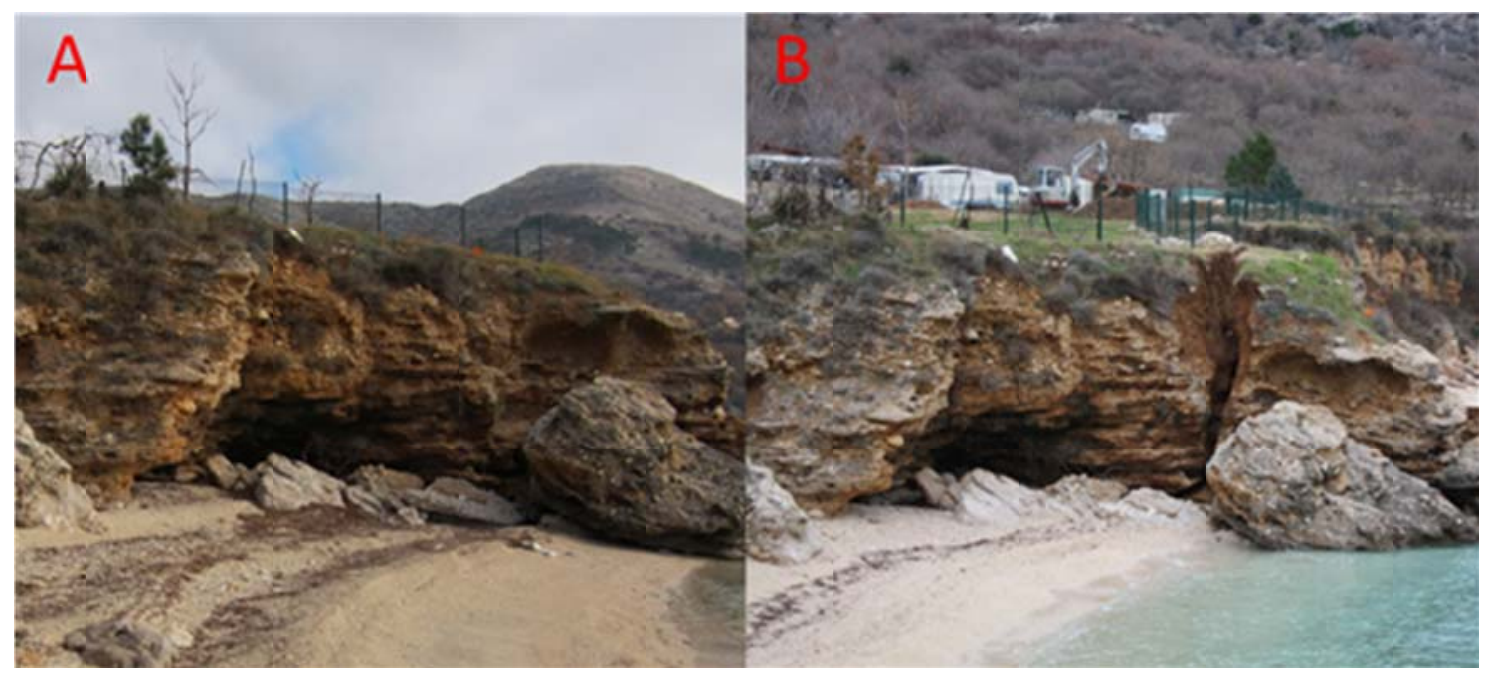

Figure 2. Before (A) and after (B) the collapse of a cliff near Stara Baška, (February 2014). 


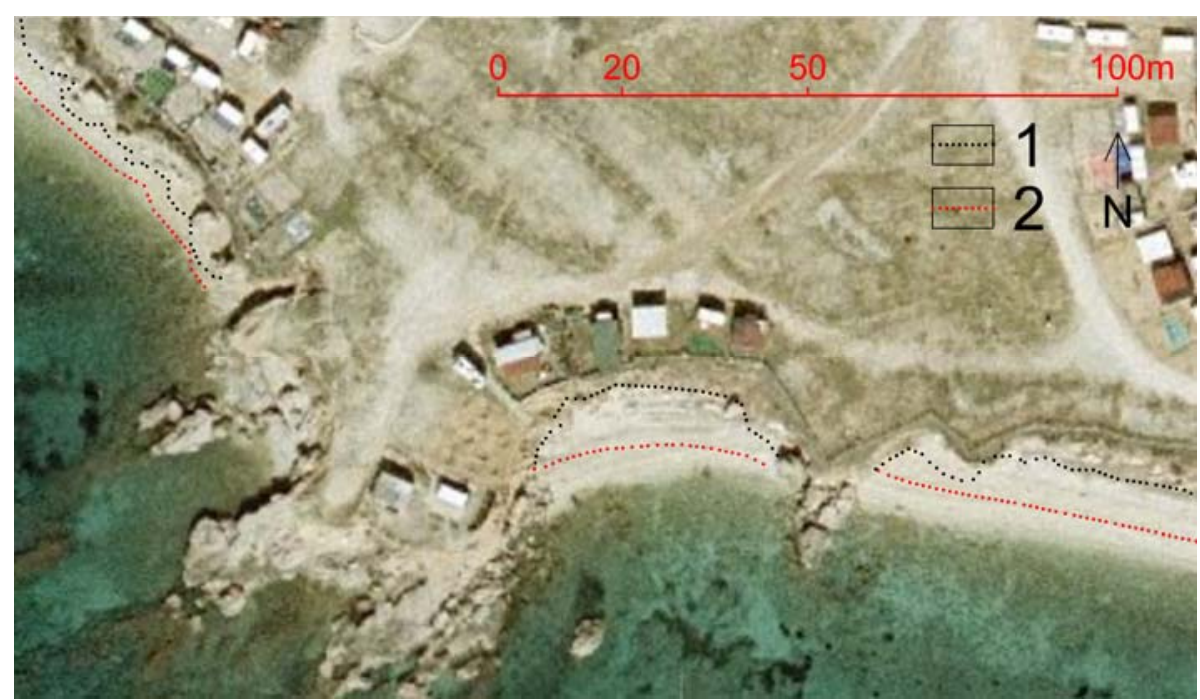

Figure 3. Coastal and cliff line changes at Stara Baška between 1966 (1) and 2004 (2).

Karstified carbonate rocks have a high degree of permeability, due to the great quantity of precipitation that can penetrate directly into the karstic ground. Surface water flows in karstic valleys occur periodically only during heavy precipitation (figure 1A). Rock mass is impermeable and has a role of the hydrogeological barrier. Talus breccias and slope deposits have distinctive filtration anisotropy. Subsurface groundwater can be accumulated locally in the clayey to silty slope material and in the weathered bedrock zone. This water originates either from direct infiltration of precipitation or from the karst aquifer above and behind the slope. Surface flow usually occurs in the cover overlying the contact with the impermeable flysch bedrock. Groundwater discharges along the coast (BENAC et al. 2013). The wave heights around Stara Baška are affected by relatively short wind fetch. Northeastern wind (bora) forms moderate waves due to small fetches, despite having the highest speed. Southeastern winds (Scirocco) generate the highest waves, up to $3.0 \mathrm{~m}$ significant wave height (figure 1B). The coast around investigated area experiences a micro-tidal regime, with a mean daily tidal range up to $0.5 \mathrm{~m}$.

Different sea levels have a significant influence on wave's propagation on beach and cliffs (figure 4$)$. Numerical simulations shows the wave $\left(\mathrm{H}^{\mathrm{S}}=2.4 \mathrm{~m}\right)$ energy dissipation for various sea levels on the embayed beach. Numerical simulations results are presented on 3D point clouds delivered from image set using Structure-from-Motion photogrammetry (RUŽIĆ et al. 2014; 2015). 


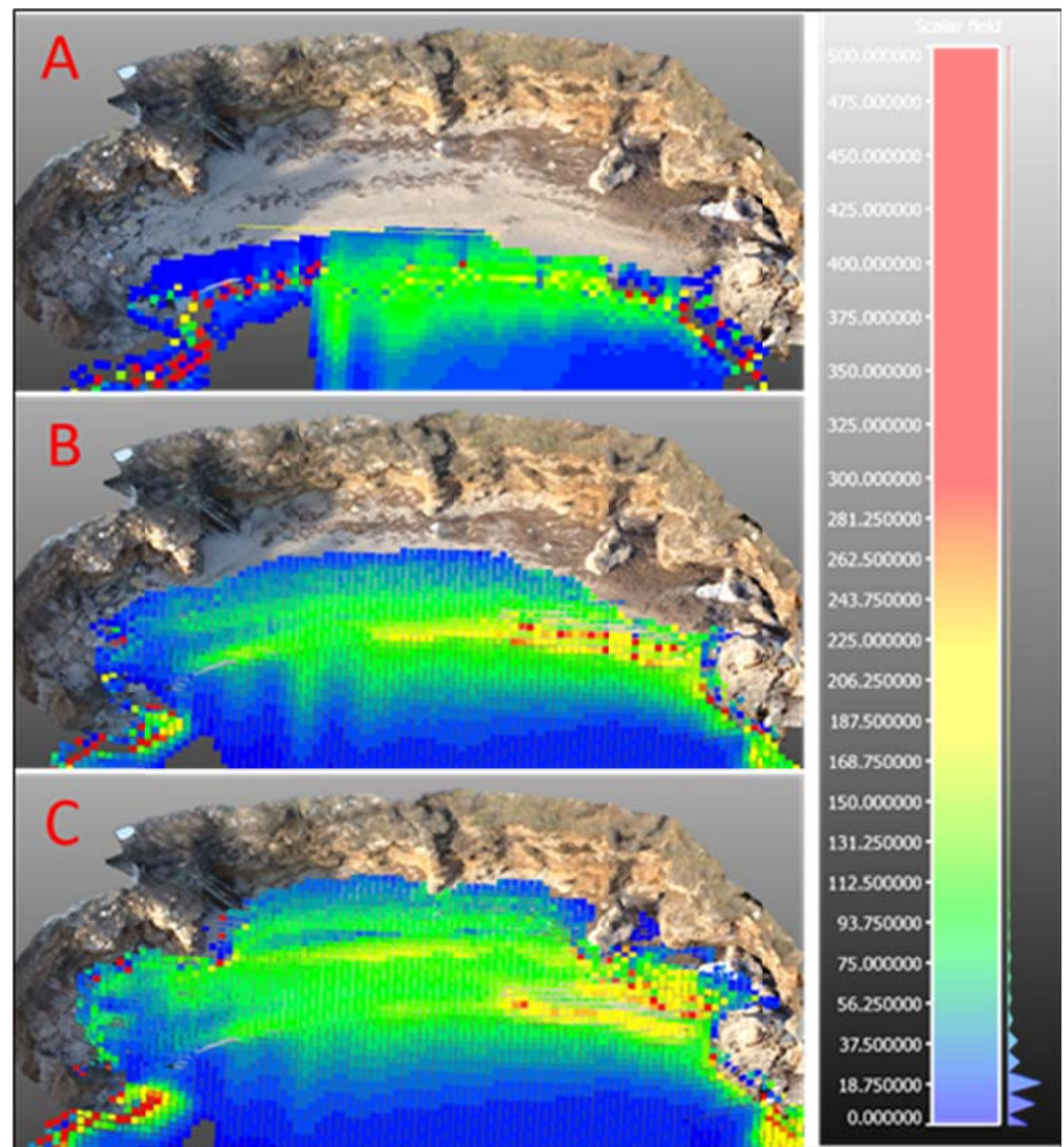

Figure 4. Wave-energy dissipation by bottom friction (wave model SWAN), SE, $H^{S}=2.4 \mathrm{~m}$. Sea level: $A$ - mean $(0.15 \mathrm{~m}), B$ - high ( $0.80 \mathrm{~m}, 1$ year return period); $C$ extreme (1.30 m, 100 year return period).

During mean and height $(0.80 \mathrm{~m})$ sea level majority of wave energy diissipation occurs on the beach body. That prevents the formation of cliff undercut and cliff retreat. During extreme $(1.30 \mathrm{~m})$ sea level, wave energy dissipation moves significantly onshore, near cliffs toe.

\section{Discussion and conclusions}

The instrumental recording has shown sea level rise in the Adriatic Sea from the middle of the $19^{\text {th }}$ century (PIRAZZOLI, 1996). Predicted sea level rise during the $21^{\text {st }}$ century is $62+/-14 \mathrm{~cm}$ (ORLIĆ \& PASARIĆ, 2013). For this reason, the flooding of beach bodies will be more frequent, and the waves will reach the shore more. Extreme sea levels will occur more often in the future because of the sea level rise. This will 
Mediterranean rocky coasts:

Features, processes, evolution and problems

generally increase cliff and beach erosion. At the investigated sight, the narrow gravel beach absorbs most of the wave mechanical energy during the mean sea levels. However, during extreme storm surges, the waves reach the cliff toe and can contribute to the cliff undercut formation and consequently a cliff retreat. It is important to investigate the relationship between the cliff erosion and beach body size, and its impact on the coastal processes.

Even now, new evidence of marine erosion caused by a combination of wave action and extreme storm surges are visible on the coast of Kvarner area. Many natural and manmade beach bodies have been eroded. Due to geological fabric, the influence of surface and underground water flow as well as periodically strong wave attacks, the coastal zone around Stara Baška settlement is currently in delicate geodynamic balance.

\section{References}

BENAC Č., JURAČIĆ M. (1998). Geomorphological indicators of the sea level changes during Upper Pleistocene, Wuerm) and Holocene in the Kvarner region. Acta Geographica Croatica, Vol. 33 (1), pp. 27-45.

BENAC Č., JURAČIĆ M., MATIČEC D., RUŽIĆ I., PIKELJ K. (2013). Fluviokarst vs. karst: examples from the Krk Island, Northern Adriatic, Croatia. Geomorphology, Vol. 184, pp. 64-73. https://doi.org/10.1016/j.geomorph.2012.11.016

JURAČIĆ M., BENAC Č., PIKELJ K., ILIĆ S. (2009). Comparison of the vulnerability of limestone (karst) and siliciclastic coasts (example from the Kvarner area, NE Adriatic, Croatia). Geomorphology, Vol. 107 (1-2), pp. 90-99. https://doi.org/10.1016/j.geomorph.2007.05.020

ORLIĆ M., PASARIĆ Z. (2013). Semi-empirical versus process-based sea-level projections for the twenty-first century. Nature Climate Change, Vol. 3, pp. 735-738. doi:10.1038/nclimate1877

PIKELJ K., JURAČIĆ M. (2013). Eastern Adriatic Coast (EAC): Geomorphology and coastal vulnerability of a karstic coast. Journal of Coastal Research, Vol. 29 (4), pp. 944-957. https://doi.org/10.2112/JCOASTRES-D-12-00136.1

PIRAZZOLI P.A. (1996). Sea level changes. The last 20.000 Years. John Wiley \& Sons, Chicester - New York, 211p.

RUŽIĆ I., MAROVIĆ I., BENAC Č., ILIĆ S. (2014). Coastal cliff geometry derived from structure-from-motion photogrammetry at Stara Baška, Krk Island, Croatia. GeoMarine Letters, Vol. 34, pp. 555-565. https://doi.org/10.1007/s00367-014-0380-4

RUŽIC I., BENAC Č., MAROVIC I., ILIC S. (2015). A stability assessment of coastal cliffs using digital imagery. Acta Geotech. Slov. 25, pp. 25-35.

TRENHAILE A.S. (2002). Rock coasts, with particular emphasis on shore platforms. Geomorphology, Vol. 48(1-3), pp. 7-22. https://doi.org/10.1016/S0169-555X(02)00173-3 